\title{
Spatial Distribution Pattern of Representative Tree Species in a Foothill Rain Forest in West Sumatra
}

\author{
Takashi KOHYAMA* Center for Ecological Research, Kyoto University, Shimosakamoto, Otsu 520-01, Japan \\ Eizi SUZUKI College of Liberal Arts, Kagoshima University, Kohrimoto, Kagoshima 890, Japan \\ Mitsuru HotTA Department of Biology, Kagoshima University, Kohrimoto, Kagoshima 890, Japan
}

\begin{abstract}
Spatial distribution was analysed for all plot trees and representative tree species in two duplicate 1-ha plots established in a foothill rain forest $16 \mathrm{~km}$ west from Padang, West Sumatra, Indonesia. All tree trunks $\geq 8 \mathrm{~cm}$ dbh were distributed randomly in both plots. Spatial correlation between dead trees and recruited trees during the 8 -year period was locally negative while broadly positive, suggesting that the random spatial pattern is dynamically maintained by mechanisms of density-dependent regulation.

All of five abundant canopy/subcanopy non-pioneer species, i.e. Hopea dryobalanoides, Gonystylus forbesii, Cleistanthus glandulosus, Mastixia trichotoma, and Grewia florida, and typical pioneer Macaranga spp., including $M$. gigantea, M. hypoleuca, M. pruinosa and M. triloba, showed a clumped distribution, particularly for smaller size classes. Two subcanopy non-pioneer species, Mastixia and Grewia showed a shift from a regularly decreasing density with height in one plot with larger gap area to bimodal height distribution in the other plot with smaller gap area. They also showed a similar tendency in spatial pattern such that the negative spatial correlation was observed between seedlings $(<1 \mathrm{~m} \mathrm{high})$ and poles (1-10 m high) and between poles and tall trees $(\geq 10 \mathrm{~m}$ high) in the plot with larger gap area but that was found between seedlings and tall trees in the plot with smaller gap area. Such pattern was also observed for gap-demanding Macaranga spp., and they were concluded to be less tolerant than Hopea, Gonystylus and Cleistanthus, in which no height distribution difference nor spatial pattern difference was observed between two plots. These more tolerant species showed a positive correlation between tall trees and seedlings, but no correlation between tall trees and poles. These results reflect the dynamic alternation of tree species within a limited area of forest.
\end{abstract}

Key Words: Cleistanthus glandulosus / Gonystylus forbesii / Grewia florida / Hopea dryobalanoides / Indonesia / Macaranga spp. / Mastixia trichotoma / spatial pattern / tropical rain forest

Recent studies on tree communities in tropical forests have paid attention to the dynamic pattern of spatial dispersion of trees. In particular, there has been considerable controversy regarding so-called Janzen-Connell hypothesis that tropical tree species diversity is promoted by a negative spatial correlation between adults and offsprings due to local density dependence (Augspurger, 1983a, b; Clark \& Clark, 1984 for a positive view; Hubbell, 1980; Hubbell, Condit \& Foster, 1990 for a negative view; Connell, Tracey \& Webb, 1984; Augspurger, 1984 for an intermediate view). Further detailed observation of spatial patterns of co-occurring tree species is necessary, particularly in species-rich Malesian rain forests. To examine the population-level consequences of spatial regulation, the observation should cover the whole population including every seedling in research plots.

This report follows the previous papers on spatial distribution pattern of an emergent tree Swintonia schwenkii (T. \& B.) T. \& B. (Suzuki \& Kohyama, 1991) and of a canopy tree Calophyllum cf. soulattri Burm. (Mukhtar et al., 1992), dealing with the same forest plots. It analyses (1) the spatial pattern of all trees collective of species with its dynamics, and (2) the

* for correspondence. 
spatial pattern of the whole population of representative tree species (other than the above two) in the two 1-ha permanent rain forest plots in West Sumatra. We conclude that the density-dependent regulation can occur at the guild level, i.e., collective of species, and that species-specific patterns should be analysed in the context of a pattern drawn for a whole guild.

\section{METHODS}

We investigated the spatial distribution pattern of representative species in duplicate 1-ha permanent plots, namely the Pinang Pinang Plot and the Gajabuih Plot, established in a foothill rain forest (alt. 590-635 m) in the Ulu Gadut area, the basin of Sungei (River) Gadut Gadang, $18 \mathrm{~km}$ east from Padang, West Sumatra; for detailed description of the sites see Kohyama et al. (1986), Suzuki \& Kohyama (1991) and Mukhtar et al. (1992). The portion of an attached belt of the Gajabuih Plot was omitted from the seedling-sapling census as in earlier studies on spatial patterns.

The 8-year dynamics of all plot trees $\geq 8 \mathrm{~cm}$ dbh was recorded in early September 1981 and mid August 1989 for the Pinang Pinang Plot and in late December 1980 and late August 1989 for the Gajabuih Plot.

In September 1989, we carried out a census of all individuals, including seedlings and saplings $<8 \mathrm{~cm}$ dbh (= trunk diameter at $1.3 \mathrm{~m}$ above the ground level) for selected representative tree species in the forest: Hopea dryobalanoides Miq. (Dipterocarpaceae), Gonystylus forbesii Gilg (Thymelaeaceae), Cleistanthus glandulosus Jabl. (Euphorbiaceae), Mastixia trichotoma Bl. (Cornaceae), Grewia florida Miq. (Tiliaceae), Macaranga spp. (Euphorbiaceae), including M. gigantea (Rochb. f. et Zoll. ) M. A., M. hypoleuca (Miq.) M. A., M. pruinosa (Miq.) M. A. and M. triloba (Bl.) M. A. Voucher specimens of these species in the plots were deposited in the Herbarium Bogoriense (BO), the Herbarium of the Department of Biology, Andalas University and the Herbarium of the Faculty of Science, Kagoshima University (KAGS).

The census for seedlings and saplings was carried out by tagging numbered tapes, measuring of top height and dbh (when taller than $1.3 \mathrm{~m}$ ), and mapping the position of the stem base. We also measured height and dbh of all trees of these species $\geq 8 \mathrm{~cm} \mathrm{dbh}$. We recorded coordinates of all individuals from dispersion maps of two plots using a digitizer, and devised a program to draw maps of any species and/or categories using a microcomputer. The dispersion maps of each species are shown in Appendices 1-6.

The spatial pattern of individuals was analysed by subdividing plots into square-grids with sides of $20,10,5$ and $2.5 \mathrm{~m}$. The arrangement of $20 \times 20$ and $10 \times 10-\mathrm{m}$ grids within two plots is shown in an earlier paper (Suzuki \& Kohyama, 1991); each of $10 \times 10$-m grids was further divided into four $5 \times 5$-m grids and sixteen $2.5 \times 2.5$-m grids. Twenty and eighteen units of $20 \times 20$-m grids were set in the Pinang Pinang and the Gajabuih Plot respectively, and marginal portion was excluded from the analysis.

We applied the statistic indices of spatial distribution and correlation of Iwao (1977). The $\mathrm{m}^{*} / \mathrm{m}$ index (the mean-crowding divided by mean density) of spatial distribution of a given population is 1 for a random distribution, $>1$ for a clumped distribution, and $<1$ for a regular distribution. This index expresses the spatial pattern independent of the number of sampled grids, and is almost identical to the $I_{\delta}$ index of Morisita (1958). Independently, we tested the 
significance of the observed distribution from the Poisson model of random distribution using $F$ tests (Morisita 1958), which is a function of the number of sampled grids. For the correlation of spatial distribution between two populations, we calculated the $\omega$ index of Iwao (1977). The $\omega$ index is zero for mutually independent distribution, positive value up to +1 for a positive correlation, and negative to -1 for a negative correlation.

\section{General description of species \\ Hopea dryobalanoides}

Species of the genus Hopea including $H$. dryobalanoides rarely grow to emergent layer of Malesian rain forests. The maximum dbh and height of $H$. dryobalanoides in two plots were $61.5 \mathrm{~cm}$ and $39.5 \mathrm{~m}$ in 1989 , respectively. This species is distributed locally frequently in Sumatra, Malay Peninsula and Borneo (Ashton, 1982). It was a common canopy-layer species around the Ulu Gadut research area. We observed mast seeding in 1989 for trees 30$40 \mathrm{~m}$ tall. This species produces dry fruits with five calyx-origin-wings, and seed dispersal is anemochorous. We observed that almost all fruit were dispersed around mother trees. Another Hopea species (not determined) was also in the plots but was rare. We could distinguish these species; while the present census of small seedlings of $H$. dryobalanoides may contain some individuals of this other species.

\section{Gonystylus forbesii}

About 20 species of the genus Gonystylus are reported from Malesian tropical rain forests, almost all from mature stands (Airy Shaw, 1953). Gonystylus forbesii and G. macrophyllus (Miq.) Airy Shaw in our research area, but the latter was rare. G. forbesii is distributed in Sumatra and Kalimantan. We recorded 26 individuals of $G$. forbesii above $8 \mathrm{~cm}$ dbh in the two 1-ha plots. The largest individual in the plots in 1989 was $27.5 \mathrm{~cm}$ in dbh and $20.5 \mathrm{~m}$ tall, but we also recorded an individual of $43.7 \mathrm{~cm}$ dbh and $27 \mathrm{~m}$ tall in the Pinang Pinang Atas Plot (transect of $10 \times 370 \mathrm{~m}$ ), located about 300-m distant from the Pinang Pinang Plot. Including largest trees, all individuals of this species occurred exclusively under the canopy layer. Flowering was observed under canopies. The fruit is capsules, exposing rather large seed (3-cm long) with dehiscence. The seeds have arils and are probably dispersed by birds and mammals.

\section{Cleistanthus glandulosus}

About 150 species of Cleistanthus are known in the paleotropics, but require taxonomic revision. In the Malay Peninsula, Whitmore (1972) described no species as very common and most as rare. We recorded two species of this genus from the Ulu Gadut area. C. glandulosus was distributed commonly, while the other $C$. sumatranus (Miq.) M.A. occurred only in riparian habitats. Among 47 individuals above $8 \mathrm{~cm}$ dbh, only two individuals were taller than $20 \mathrm{~m}$ in top height $(22.4 \mathrm{~m}$ with $29.1 \mathrm{~cm}$ dbh and $20.5 \mathrm{~m}$ with $29.2 \mathrm{~cm} \mathrm{dbh}$ ). Mortality over 10 years was low; only one tree died. This species is most abundant under the canopy layer. We observed fruiting only once in a stand-edge tree. The fruit is capsules, and seeds with red arils are probably dispersed by birds.

\section{Mastixia trichotoma}

The genus Mastixia is characterized by an opposite leaf orientation. Thirteen species are reported from south-east Asia and southern India, Sri Lanka, and north-east India; they often require moist habitat and never become emergent trees (Mathew, 1977). In the Ulu Gadut 


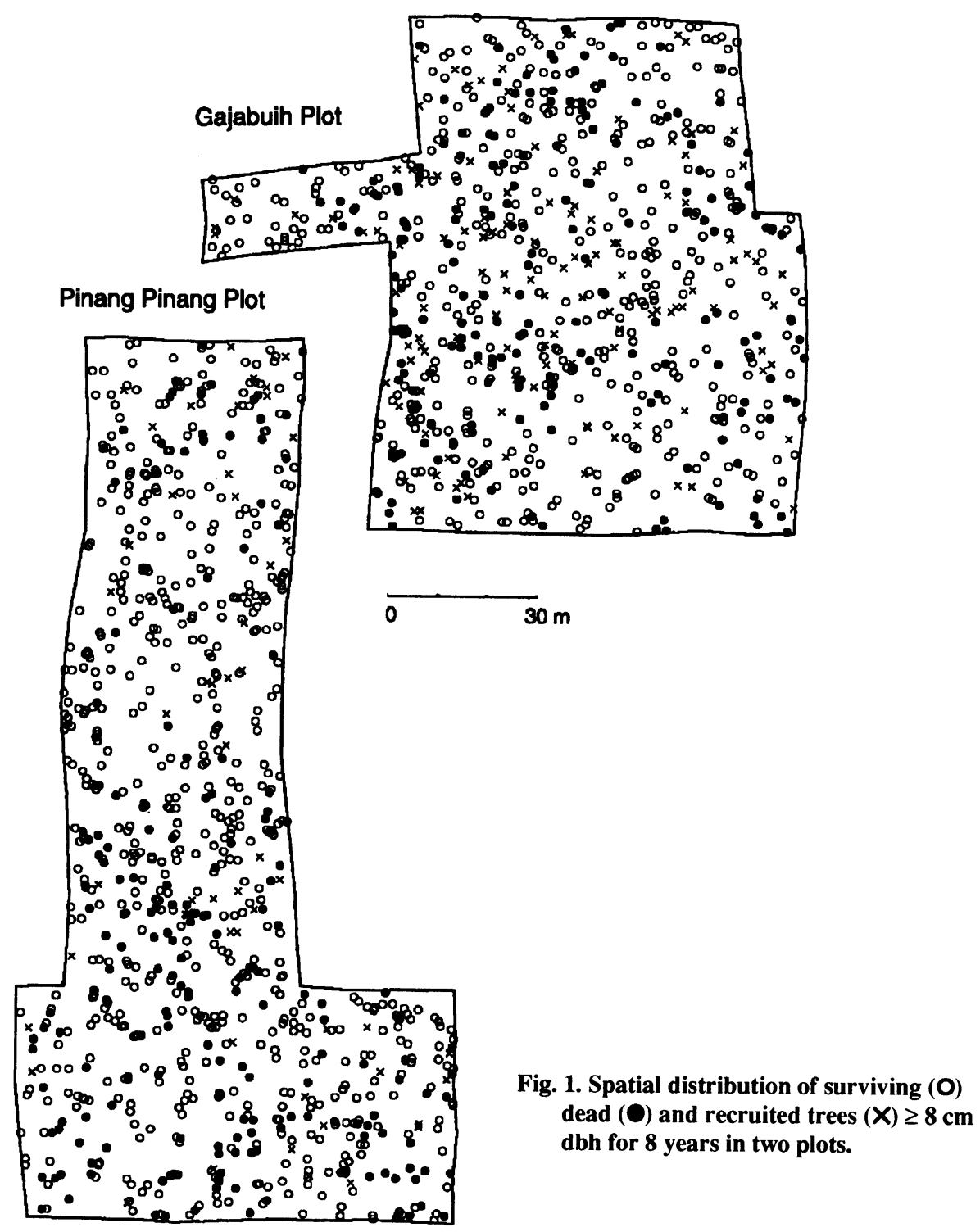

area, $M$. trichotoma occurs relatively dry site along ridge, perhaps due to the extremely moist climate of the area. This species is widely distributed over Malesia, and Mathew (1977) subdivided it into five varieties. We think the population in Ulu Gadut is M. trichotoma var. clarkeana (King) Danser, but so far we lack flowering material. A dense population of $M$. trichotoma with trees of various size can be observed in the Pinang Pinang Plot, with a maximum height of $25.1 \mathrm{~m}$ in 1989 . The fruits are subglobose drupes growing to $2-3 \mathrm{~cm}$ (Mathew, 1977), supposed to be dispersed by birds and mammals. We observed no flowering over the 10 years but there were many saplings in the study area, so dispersal seems to be efficient and the probability of establishment success is high.

\section{Grewia florida}

The genus Grewia and the division between the genera Grewia and Microcos is in need of taxonomic reexamination. In the Ulu Gadut research area, we found two species of Grewia; 
mostly G. florida, which is distributed in Sumatra and Malay Peninsula (Ridley, 1922), and only one tree of another undetermined species in the Pinang Pinang Atas Plot. G. florida is distributed as an under canopy species in mature rain forests, but can be part of a canopy layer in secondary stands. This species has an intermediate tendency between climax and pioneer. The maximum height observed in our plots was $25.9 \mathrm{~m}$. Fruiting was observed for 10-m tall individuals at stand edges. Fresh drupes contained many hard small seeds adapted to animal dispersion.

\section{Macaranga spp.}

We recorded 10-year changes in the dbh of 63 trees of the genus Macaranga in the two 1-ha plots, i.e. M. gigantea (3 trees), M. hypoleuca (14), M. pruinosa (6) and M. triloba (40). Our record of $M$. triloba may contain $M$. indistincta Whitmore. It is easy to distinguish these four species at an adult stage, but quite difficult at the small seedling stage. Therefore in this paper, these populations are put together. There exists, however, clear differences among these species in ecological habit. M. hypoleuca and $M$. pruinosa have rather small leaf blade, leathery an deeply trilobed, and form densely foliated crowns. $M$. gigantea has large leaves and dense crowns. These three species are typical light demanders and no recruitment was observed under closed canopies. They occurred at canopy top (78\% of them were taller than $20 \mathrm{~m}$ ). Both mortality and recruitment rates were exceptionally high. In contrast, $M$. triloba (and relatives) has relatively thin leaves and their crowns have a rather low foliage density. Trees taller than $20 \mathrm{~m}$ were only $7.5 \%$ of the whole population $\geq 8 \mathrm{~cm}$. The $M$. triloba group is presumed to be slightly more shade tolerant than the other species. Species of Macaranga produce capsules. They are known to have seed dormancy; the germination is induced by direct light (Longman \& Jeník, 1987).

\section{RESULTS}

\section{Spatial pattern for all trees irrespective of species}

All plot trees $\geq 8 \mathrm{~cm}$ dbh throughout the census period showed a random distribution in both plots. There were no clear differences between larger $(\geq 20 \mathrm{~cm} \mathrm{dbh})$ and smaller $(8-20 \mathrm{~cm}$ dbh) trees, nor between the two plots (Table 1). Two size classes distributed mutually independently (Table 2).

The spatial pattern of surviving, dead and recruited trees over 8 years is shown in Fig. 1.

Table 1. Number of individuals and $\mathrm{m}^{*} / \mathrm{m}$ index of spatial distribution (Iwao, 1977) in four grid classes in alive, dead and recruited trees ( $\geq 8 \mathrm{~cm} \mathrm{dbh}$ ) for 1980(1)-1989 period; and those for small trees $8-20 \mathrm{~cm}$ dbh and large trees $\geq 20 \mathrm{~cm}$ dbh in 1989 .

\begin{tabular}{|c|c|c|c|c|c|c|c|c|c|c|}
\hline \multirow[t]{2}{*}{ Categories } & \multicolumn{5}{|c|}{ Pinang Pinang Plot } & \multicolumn{5}{|c|}{ Gajabuih Plot } \\
\hline & Indiv. 2 & $2.5 \times 2.5 \mathrm{~m}$ & $5 \times 5 \mathrm{~m}$ & $10 \times 10 \mathrm{~m}$ & $0 \times 20 \mathrm{~m}$ & \# Indiv. & $2.5 \times 2.5 n$ & $\mathrm{n} 5 \times 5 \mathrm{~m}$ & $10 \times 10 \mathrm{~m}$ & $20 \times 20 \mathrm{~m}$ \\
\hline living for 8 years & 482 & 1.19 & 1.16 & 1.08 & 1.02 & 348 & 1.26 & 1.04 & 1.05 & 1.03 \\
\hline dead during 8 years & 42 & 10.16 & 2.90 & 1.72 & 1.32 & 109 & 0.97 & 0.82 & 1.08 & 1.15 \\
\hline recruited during 8 years & s 157 & 1.04 & 1.22 & 1.19 & 1.23 & 141 & 1.04 & 0.99 & 1.14 & 1.23 \\
\hline $\mathrm{dbh}<20 \mathrm{~cm}$ in 1989 & 439 & 0.97 & 1.08 & 1.03 & 1.02 & 359 & 1.11 & 0.99 & 1.10 & 1.09 \\
\hline $\mathrm{dbh} \geq 20 \mathrm{~cm}$ in 1989 & 200 & 1.15 & 1.09 & 1.18 & 1.04 & 130 & 1.23 & 0.92 & 0.95 & 0.92 \\
\hline
\end{tabular}

Significant clumped distribution from the Poisson distribution at $1 \%$ level are expressed by bold-face. 
Table 2. $\omega$ index (Iwao, 1977) of spatial correlation in four grid classes between alive, dead and recruited trees ( $\geq 8 \mathrm{~cm} \mathrm{dbh}$ ), for 1980 (1)-1989 period; and that between small tree $<20 \mathrm{~cm}$ dbh and large tree $\geq 20 \mathrm{~cm}$ dbh in 1989.

\begin{tabular}{|c|c|c|c|c|c|c|c|c|}
\hline \multirow[t]{2}{*}{ Categories } & \multicolumn{4}{|c|}{ Pinang Pinang Plot } & \multicolumn{4}{|c|}{ Gajabuih Plot } \\
\hline & $2.5 \times 2.5 \mathrm{~m}$ & $5 \times 5 \mathrm{~m}$ & $10 \times 10 \mathrm{~m}$ & $20 \times 20 \mathrm{~m}$ & $2.5 \times 2.5 \mathrm{~m}$ & $5 \times 5 \mathrm{~m}$ & $10 \times 10 \mathrm{~m}$ & $20 \times 20 \mathrm{~m}$ \\
\hline alive vs. dead & $\underline{-0.30}$ & $\underline{-0.12}$ & -0.01 & -0.01 & -0.21 & $\underline{-0.19}$ & -0.01 & +0.09 \\
\hline alive vs. recruited & +0.00 & -0.07 & -0.09 & -0.07 & +0.01 & -0.03 & +0.07 & +0.17 \\
\hline dead vs. recruited & $\underline{-0.61}$ & +0.02 & -0.09 & +0.17 & $\underline{-0.33}$ & +0.06 & +0.18 & +0.23 \\
\hline small vs. large & +0.06 & +0.07 & -0.01 & -0.03 & +0.03 & +0.04 & +0.00 & +0.03 \\
\hline
\end{tabular}

Positive index $\geq+0.10$ is shown by bold-face; negative index $\leq-0.10$ by bold-face underline.

The 8-year dynamics of tree populations revealed that dead trees was distributed in clumped manner in the Pinang Pinang Plot, while not in the Gajabuih Plot (Table 1). It reflects the scattered distribution of gaps in the Pinang Pinang Plot (Kohyama et al., 1989; Suzuki \& Kohyama, 1991). Recruitment of trees was also clumped in a large unit of $20 \times 20$-m (Table 1). Dead trees were negatively correlated with living trees in smaller units of $2.5 \times 2.5$ and 5 $\times 5 \mathrm{~m}$ in the two plots, but no spatial correlation was detected between recruited trees and living trees (Table 2). In both plots dead trees were negatively correlated with recruited trees at the small scale of $2.5 \times 2.5$-m units, but were positively correlated at the larger scale of 20 $\times 20$-m units (Table 2 ).

\section{Spatial pattern for each species}

Each species examined showed clumped distributions of its smaller size classes (Table 3). The populations of large trees of each species showed regular distribution in terms of $\mathrm{m} * / \mathrm{m}$ (Table 3), but these populations were not significantly different from a random distribution due to small samples.

Various patterns of spatial correlation were found between size classes within species. Mastixia and Grewia both showed the same in the difference between the two plots (Table 4). In the degenerated Gajabuih Plot which had a larger and extending gap area, negative correlation was found between poles (1-10 m) and tall trees ( $\geq 10 \mathrm{~m})$ and between seedlings $(<1 \mathrm{~m})$ and poles, and positive correlation existed between seedlings and tall trees. In the Pinang Pinang Plot, the opposite pattern was the case for these two species. Macaranga spp. also showed a difference in spatial correlation between two plots. By contrast, Hopea, Gonystylus and Cleistanthus showed a similar pattern of spatial correlation between size classes in both plots. These three species had a positive correlation between tall trees and seedlings, but no positive correlation between poles and tall trees.

The above species characteristics in spatial correlation pattern in both plots concurred with those in size structure. Figure 2 shows the height distribution of the species examined and the emergent-dominant Swintonia schwenkii (cf. Suzuki \& Kohyama, 1991). Mastixia and Grewia had a regularly decreasing height distribution in Gajabuih Plot, and a bimodal distribution with a group of higher trees in Pinang Pinang Plot. Such difference in height distribution between two plots was more clearly observed in light-demandi..g Macaranga. The height distribution of Hopea, Gonystylus and Cleistanthus was similar between two plots, and the regularly decreasing distribution. Overall results suggest that the degenerated Gajabuih Plot with large gap area represents a younger stage than the Pinang Pinang Plot 
Table 3. Number of individuals and $\mathrm{m}^{*} / \mathrm{m}$ index (Iwao, 1977) of spatial distribution in three mesh sizes, for each species in three top-height classes.

\begin{tabular}{|c|c|c|c|c|c|c|c|c|c|}
\hline \multirow[t]{2}{*}{ Species } & \multirow{2}{*}{$\begin{array}{l}\text { Height } \\
\text { class }\end{array}$} & \multicolumn{4}{|c|}{ Pinang Pinang Plot } & \multicolumn{4}{|c|}{ Gajabuih Plot } \\
\hline & & \# Indiv. & $5 \times 5 \mathrm{~m}$ & $10 \times 10 \mathrm{~m}$ & $20 \times 20 \mathrm{~m}$ & \# Indiv. & $5 \times 5 \mathrm{~m}$ & $10 \times 10 \mathrm{~m}$ & $20 \times 20 \mathrm{~m}$ \\
\hline \multirow{3}{*}{$\begin{array}{l}\text { Hopea dryobala- } \\
\text { noides }\end{array}$} & $<1 \mathrm{~m}$ & 117 & 18.47 & 10.75 & 8.79 & 72 & 24.22 & 12.58 & 5.54 \\
\hline & $1-10 \mathrm{~m}$ & 112 & 3.57 & 2.97 & 2.21 & 60 & 7.36 & 4.24 & 3.01 \\
\hline & $\geq 10 \mathrm{~m}$ & 11 & 0.00 & 0.00 & 1.98 & 6 & 0.00 & 0.00 & 1.00 \\
\hline \multirow[t]{3}{*}{ Gonystylus forbesii } & $<1 \mathrm{~m}$ & 57 & 3.15 & 2.41 & 1.88 & 39 & 3.79 & 2.18 & 1.47 \\
\hline & $1-10 \mathrm{~m}$ & 119 & 2.35 & 1.89 & 1.61 & 84 & 1.31 & 1.39 & 1.06 \\
\hline & $\geq 10 \mathrm{~m}$ & 8 & 0.00 & 0.00 & 0.00 & 12 & 0.00 & 0.00 & 0.50 \\
\hline \multirow{3}{*}{$\begin{array}{l}\text { Cleistanthus gran- } \\
\text { dulosus }\end{array}$} & $<1 \mathrm{~m}$ & 340 & 2.39 & 1.79 & 1.60 & 82 & 4.80 & 2.83 & 1.94 \\
\hline & $1-10 \mathrm{~m}$ & 425 & 2.16 & 1.69 & 1.51 & 235 & 2.24 & 1.77 & 1.27 \\
\hline & $\geq 10 \mathrm{~m}$ & 22 & 0.00 & 1.32 & 0.83 & 9 & 0.00 & 0.00 & 0.89 \\
\hline \multirow[t]{3}{*}{ Mastixia trichotoma } & $<1 \mathrm{~m}$ & 222 & 3.97 & 3.30 & 2.18 & 65 & 3.68 & 2.42 & 1.41 \\
\hline & $1-10 \mathrm{~m}$ & 46 & 3.03 & 2.04 & 1.74 & 24 & 0.00 & 0.50 & 0.69 \\
\hline & $\geq 10 \mathrm{~m}$ & 22 & 5.29 & 2.31 & 2.07 & 2 & 0.00 & 0.00 & 0.00 \\
\hline \multirow[t]{3}{*}{ Grewia florida } & $<1 \mathrm{~m}$ & 97 & 3.26 & 1.96 & 1.23 & 51 & 1.99 & 1.72 & 1.17 \\
\hline & $1-10 \mathrm{~m}$ & 55 & 0.85 & 1.38 & 1.31 & 34 & 2.49 & 0.75 & 1.09 \\
\hline & $\geq 10 \mathrm{~m}$ & 23 & 1.21 & 1.51 & 1.29 & 4 & 0.00 & 0.00 & 2.25 \\
\hline \multirow[t]{3}{*}{ Macaranga spp. } & $<1 \mathrm{~m}$ & 126 & 26.65 & 18.80 & 7.13 & 57 & 3.01 & 1.77 & 1.72 \\
\hline & $1-10 \mathrm{~m}$ & 12 & 8.89 & 2.22 & 1.39 & 47 & 4.17 & 2.48 & 1.79 \\
\hline & $\geq 10 \mathrm{~m}$ & 24 & 2.22 & 2.78 & 2.29 & 13 & 13.63 & 3.41 & 1.07 \\
\hline
\end{tabular}

Significant clumped distribution from poisson distribution at $1 \%$ level are shown by bold-face.

Table 4. $\omega$ index (Iwao, 1977) of spatial correlation in three mesh sizes between three height classes, for each species.

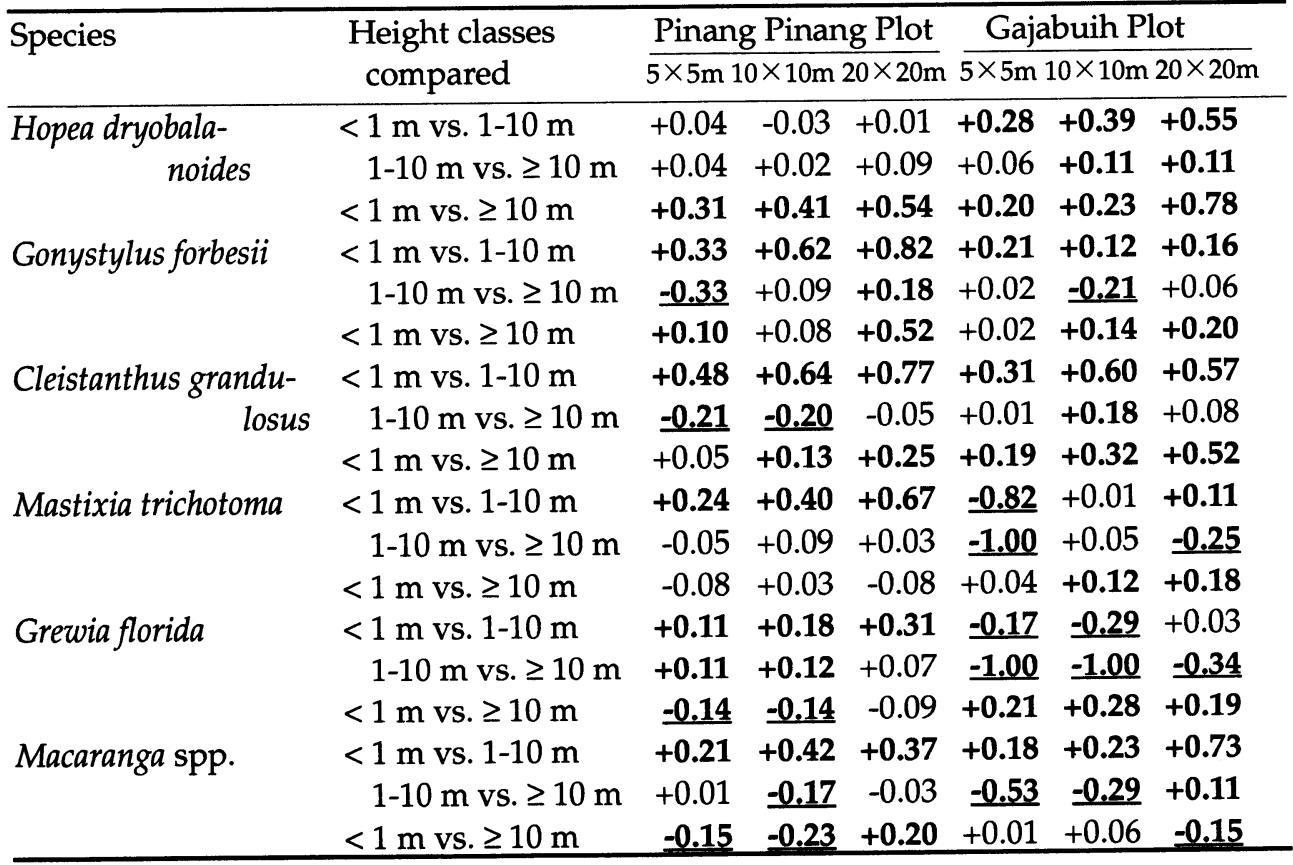

Positive index $\geq+0.10$ is shown by bold-face; negative index $\leq-0.10$ by bold-face underline. 
Pinang Pinang Plot

Gajabuih Plot

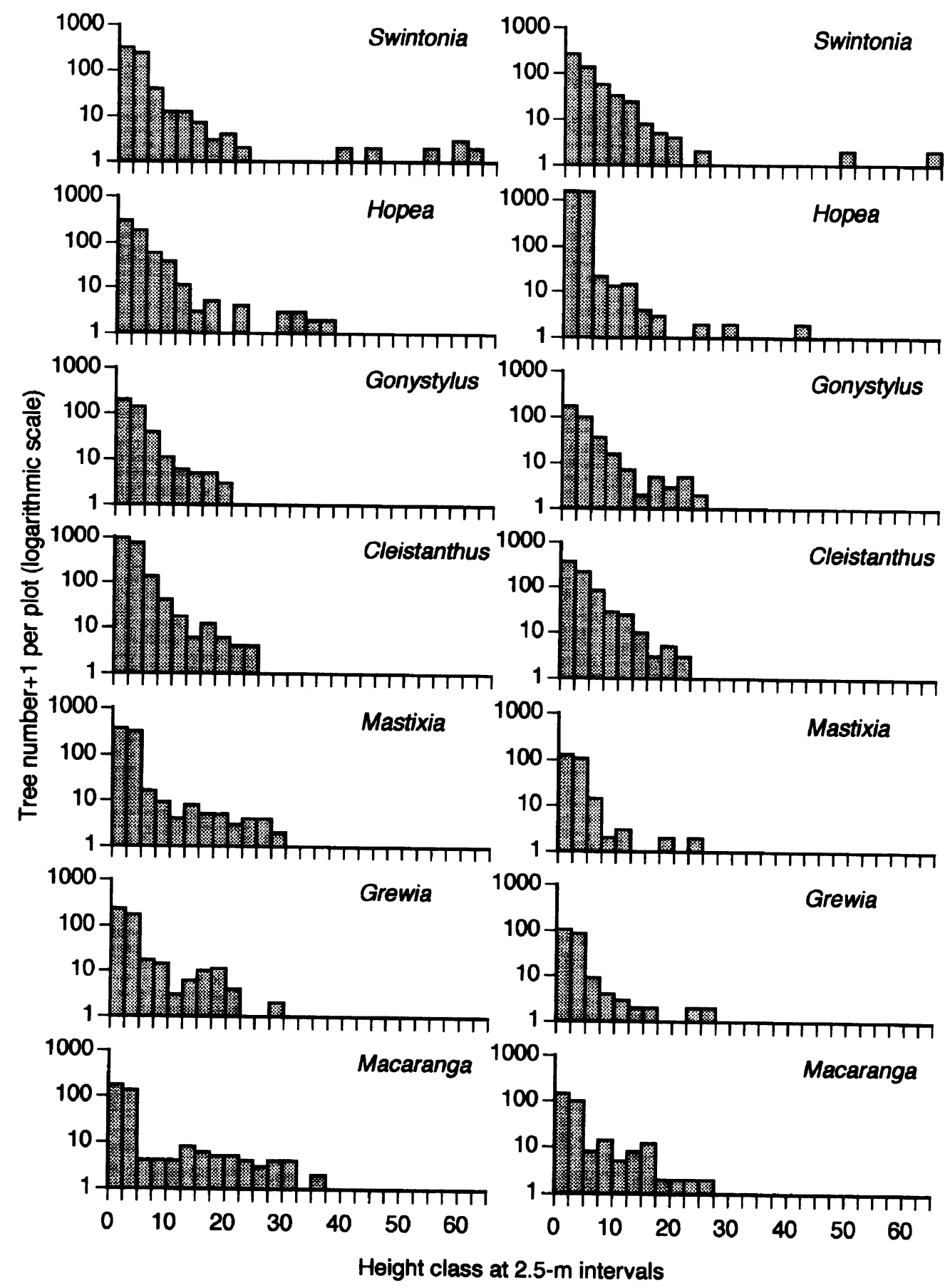

Fig. 2. Top height distribution of trees for species examined in two plots.

covered mostly by mature closed canopies; Mastixia, Grewia, and Macaranga change their local population structure in size and spatial distribution with stand development, while more tolerant Hopea, Gonystylus and Cleistanthus keep their population stably independent of the developmental stage of stands. 


\section{DISCUSSION}

Regulation of spatial pattern occurs in terms of a whole guild of tree populations, as the fundamental requirements are the same between co-occurring trees irrespective of species. Apparent random dispersion of all trees is caused by local density-dependent regulation, as the process of death and recruitment shows non-random local pattern and spatial correlation. Local crowding at a small spatial scale (resulting in the negative correlation between dead and recruited stems) and the existence of sites with faster tree replacement, such as gaps, at a lager spatial scale (resulting in the positive correlation between them) simultaneously regulate the stand-level random spacing of trees. The regeneration behaviour of each species is controlled by such a whole tree-level constraint. Species-specific pattern should be therefore analysed in the context of the overall guild of forest trees; results of spatial pattern analysis without information about overall tree distribution (cf. Sterner, Ribic \& Schatz, 1986) are difficult to evaluate.

Each species with its own traits takes part in the stand-level regulation of spatial pattern, resulting into species-specific pattern of aggregation and intraspecific negative spatial correlation between size classes. A simple view of topographic segregation among species does not explain the observed pattern, because none of the species we examined showed a clumped pattern with stable positive auto-correlation between size classes.

Mastixia and Grewia are recognized to be more sensitive to gap dynamics than Hopea, Gonystylus or Cleistanthus. Their size structure is different in a degenerated plot with larger gap area than in a well-closed plot with smaller gap area, and the pattern of spatial correlation between size classes changes with the stage of forest plots. They are similar to Calophyllum cf. soulattri which has a unimodal distribution of poles, without tall trees nor seedlings, in the Gajabuih Plot and a bimodal distribution with a few canopy trees and dense seedlings in the Pinang Pinang Plot (Mukhtar et al., 1992). We found that the emergent dominant Swintonia schwenkii showed a clear negative correlation between adult trees and seedlings (Suzuki \& Kohyama, 1991). Again in Swintonia population, the bimodality in size distribution was more obvious in the Pinang Pinang Plot (Fig. 1). In the Gajabuih Plot, pole class (1-10 m tall) of Swintonia was dominant among the whole local population. Therefore, we can conclude that there is a syndrome of species traits that (1) the adult-offspring negative correlation is locally distinguishable in closed stands, (2) the size distribution tends to show a bimodality there, and (3) rather patchy and spontaneous regeneration occurs in relation to the stand development in shifting gap mosaic. Species with this syndrome we found in our research plots will be less shade-tolerant than species with the counter syndrome, i.e. (1') there is no obvious negative correlation between adults and offsprings, (2') the size distribution is stably inverse-J shaped, and (3') the regeneration success tends to be independent of gap dynamics. We could not find any clear relationship between the above population-level syndromes and allometric traits of the branching architecture of saplings (Kohyama \& Hotta, 1990). It is worth mentioning, further, that the types of seed dispersal are not related to the above regeneration syndromes. Processes after seedling establishment are more important in generating the species pattern of local populations.

The present results suggest that the phenomenon of adult versus offspring segregation employed by the Janzen-Connell hypothesis is rather commonly observed for a particular 
guild of trees in the research site. Further, the coincidence between spatial correlation and height class distribution suggests that the apparent negative correlation among size classes of a given species can be understood in relation to gap dynamics. The negative correlation among size classes is possibly related to the regeneration limitation and the resulting heterogenous structure of local populations. The contribution of the observed negative correlation to the maintenance of species diversity is yet open question until we will relate it to stand-level dynamics and evaluate it with reasonable whole-population simulators.

Within the category of non-pioneer tree species (Swaine \& Whitmore, 1988), there exists a gradient of species traits in terms of shade tolerance throughout their life histories. For instance, we cannot say any of Swintonia, Calophyllum, Mastixia and Grewia, exhibiting the gap mosaic-sensitive syndrome, is a pioneer like Macaranga spp., because they establish and maintain a dense seedling bank under the closed canopy. The effects of gap dynamics should differ among species and should be evident in a species' spatial pattern and spatial autocorrelation at different stages of stand development. To understand species-specific patterns of spatial dynamics, it is necessary to carry out comparative studies between many cooccurring tree species.

ACKNOWLEDGEMENTS We are grateful to Kazuhiko Ogino, Soedarsono Riswan, Rusjdi Tamin, Syahbuddin, Marlis Rahman and Erizal Mukhtar for kind support during our field research. We also thank Peter Bellingham and Tamiji Inoue for valuable comments on an earlier draft. The field research was funded by the International Scientific Research Program of the Ministry of Education, Science and Culture, Japan (01041074) and sponsored by the Indonesian Institute of Science.

\section{REFERENCES}

Airy Shaw, H. K. 1953. Thymelaeaceae-Gonystyloideae. In: van Steenis, C. G. G. J. (gen. ed.), Flora Malesiana ser. I 4: 349-365.

Ashton, P. S. 1982. Dipterocarpaceae. In: van Steenis, C.G.G.J. (gen. ed.), Flora Malesiana ser. I 9: 237-552.

Augspurger, C. K. 1983a. Offspring recruitment around tropical trees: changes in cohort distance with time. Oikos 40: 189-196.

- 1983b. Seed dispersal of the tropical tree, Platypodium elegans, and the escape of its seedlings from fungal pathogens. Journal of Ecology 71: 759-771.

- 1984. Seedling survival of tropical tree species: interactions of dispersal distance, light-gaps, and pathogens. Ecology 65: 1705-1712.

Clark, D. A. \& Clark, D. B. 1984. Spacing dynamics of a tropical rain forest tree: evaluation of the Janzen-Connell model. American Naturalist 124: 769-788.

Connell, J. H., Tracey, J. G. \& Webb, L. J. 1984. Compensatory recruitment, growth, and mortality as factors maintaining rain forest tree diversity. Ecological Monographs 54: 141-164.

Hubbell, S. P. 1980. Seed predation and the coexistence of tree species in tropical forests. Oikos 35: 214-229.

—, Condit, R. \& Foster, R. B. 1990. Presence and absence of density dependence in a neotropical tree community. Philosophical Transactions of Royal Society, London, B 330: 
269-281.

Iwao, S. 1977. Analysis of spatial association between two species based of the interspecies mean crowding. Researches on Population Ecology 18: 243-260.

Kohyama, T. \& Hotta, M. 1990. Significance of allometry in tropical saplings. Functional Ecology 4: 515-521.

— Hotta, M., Ogino, K., Syahbuddin \& Mukhtar, E. 1989. Structure and dynamics of forest stands in Gunung Gadut, West Sumatra. In:M. Hotta (ed.), Diversity and PlantAnimal Interaction in Equatorial Rain Forests. Occasional Papers of the Kagoshima University Research Center for the South Pacific 16: 33-47.

Longman, K. A. \& Jeník, J. 1987. Tropical Forest and Its Environment (2nd ed). Longman Scientific \& Technical, Essex.

Mathew, K. M. 1977. Cornaceae. In: van Steenis, C.G.G.J. (gen. ed.), Flora Malesiana ser. I 8: 85-97.

Morisita, M. 1959. Measuring of the dispersion of individuals and analysis of the distributional patterns. Memoirs of the Faculty of Science, Kyushu University, ser. E (Biology) 2: 215-235.

Mukhtar, E., Suzuki, E., Kohyama, T. \& Rahman, M. 1992. Regeneration process of a climax species Calophyllum cf. soulattri in tropical rain forest of West Sumatra. Tropics 2: 1-12.

Ridley, H. N. 1922. The Flora of the Malay Peninsula, vol. 1. L. Reeve \& Co. Ltd., London.

Sterner, R. W., Ribic, C. A. \& Schatz, G. E. 1986. Testing for life historical changes in spatial patterns of four tropical tree species. Journal of Ecology 74: 621-633.

Suzuki, E. \& Kohyama, T. 1991. Spatial distributions of wind-dispersed fruits and trees of Swintonia schwenkii (Anacardiaceae) in a tropical forest of West Sumatra. Tropics 1: 131142.

Swaine, M. D. \& Whitmore, T. C. 1988. On the definition of ecological species groups in tropical rain forests. Vegetatio 75: 81-86.

Whitmore, T. C. 1972. Euphorbiaceae. In: Whitmore, T. C. (ed.), Tree Flora of Malaya 2: 34136. Longman Malaysia, Kuala Lumpur.

Received June 24, 1993

Accepted July 26, 1994

\section{甲山隆司，鈴木英治，堀田満＼cjkstart西スマトラ州の熱帯山麓雨林における主要樹種の 空間分布パターン}

西スマトラ州のパダン市16 km西方に位置する二つの1 ha継続調査プロットで, 全林木集団と主 要樹種個体群の空間分布を解析した。胸高直径 $8 \mathrm{~cm}$ 以上の全林木は両プロットで機会分布をし ていた。 8 年間の調查期間中に枯死した個体と新規加入した個体は小区画単位 $(2.5 \mathrm{~m}$ メッシュ) では背反的に出現したが, 大区画 $(20 \mathrm{~m}$ メッシュ) では同所的に現われる傾向を示した。これ は，機会分布が，非機会的な密度依存制御のもとに，動的に維持されていることを示唆する。

林冠および重林冠性の非パイオニア種 5 種, Hopea dryobalanoides, Gonystylus forbesii, Cleistanthus glandulosus, Mastixia trichotoma，およびGrewia florida と，典型的なパイオニア種で あるMacaranga 属（M. gigantea, M. hypoleuca, M. pruinosa と M. triloba）は，いずれも集中分 布をしており，特に実生では集中性が顕著だった。亜林冠性の 2 種 Mastixia と Grewia は，ギ ヤップの面積比の高いプロットでは逆J字型の安定的なサイズ分布を示していたが, ギャップ比 の低いプロットでは成木と後継集団からなるふた山分布をしていた。これら 2 種は, 空間分布で も似た傾向を示した。すなわち, ギャップ比の高いプロットでは実生（高さく $1 \mathrm{~m} ）$ と幼木（1- 
$10 \mathrm{~m})$ の間，および幼木と高木（ $\geq 10 \mathrm{~m})$ の間に負の分布相関があり，実生と高木の間には正 の分布相関があったが，ギャップ比の低いプロットでは，これらの相関関係が入れ替わって，実 生と高木の間に負の分布相関が認められた。同様の傾向はギャップ依存性の Macaranga 属にも 認められたので, これら 2 種は，両プロット間で明瞭な変化傾向を示さなかったHopea， Gonystylus およびCleistanthus よりも耐陰性に劣るものと考えた。より耐陰性が高いと思われた グループでは，実生と高木の間に正の分布相関が認められたが，高木と幼木の間に明暸な相関 関係はなかった。以上の結果は，林内の限られた空間のなかで動的な種の交代が常に行われて いることを示唆するものである。 

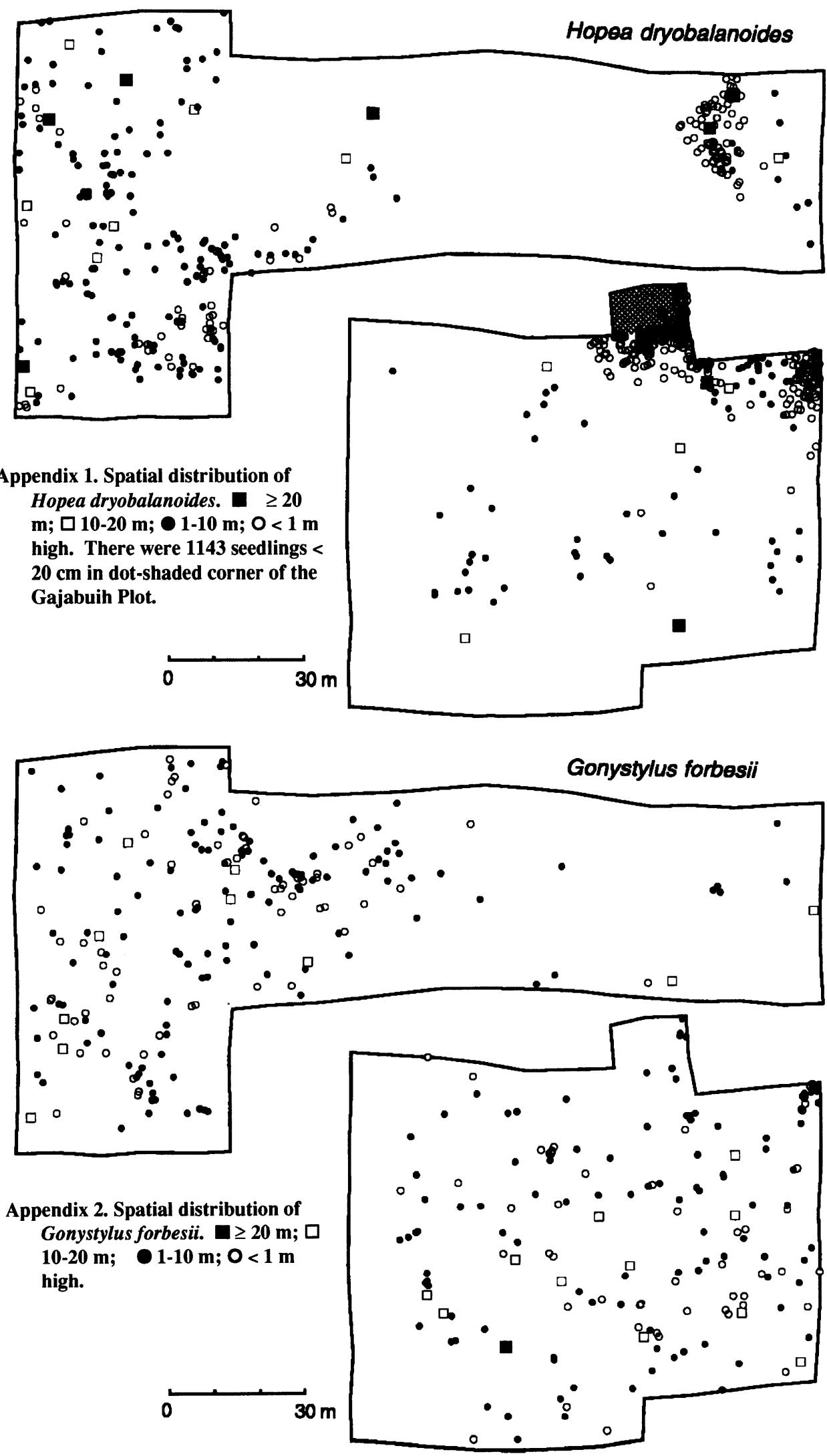

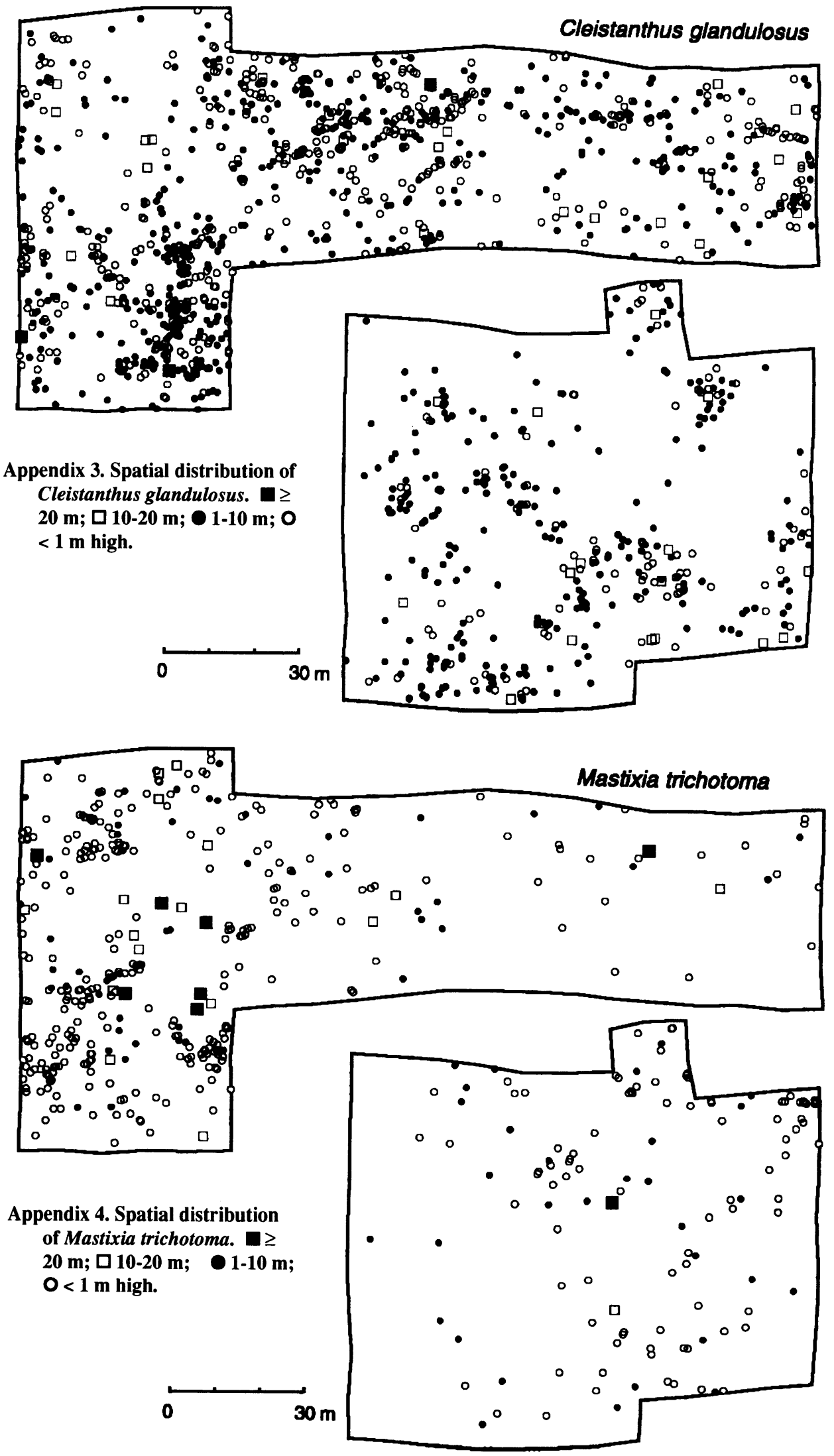

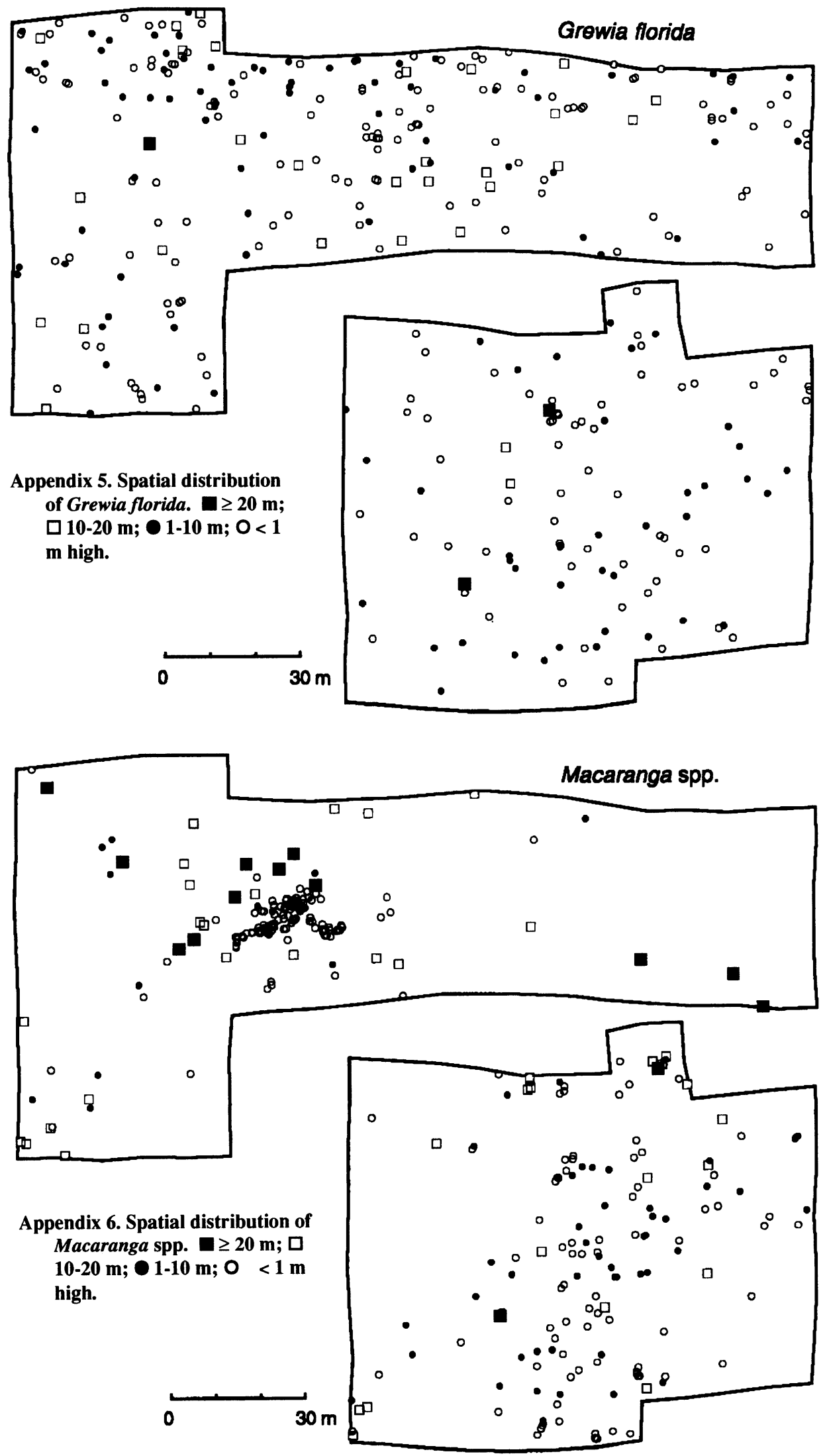